\section{川崎市役所獣医師会会報}

川崎市勤務獣医師会 (新 治会長) では,「川崎市役
所獣医師会会報」（編集人 和田 明氏）を毎月編集発 行し，勤務獣医師会員の相互の情報の交流に努めてい る.

＜論説＞科学技術者としての獣医師のありよう（その25）

\title{
日本獣医師会会長 中 村 寛
}

\section{5. 江戸の水はロンドンに通じている}

つい 100 年程前, わが国は開国と攘夷に国論が二分し 血腥い事件が次から次に派生し，そのために多数の尊い 生命が失われた。このことは今から考学ると拈よそ想像 もできないことであるが，当時は極めて重大な事柄であ り,開国論者は「江戸の水はイギリスはロンドンに通じて いる」といら名句をはいてその重要性を力説したのであ る.この言葉は極めて当然のことを当然に表現したので あるが, 私は今な拉新しい言葉であると感じている.わが 国では獣医・畜産学は極めて狭い, しかも特殊な学問とし て長い間世人に殆えど知られることもなく推移したよう に思われる．僅かに市川厚一・山極勝三郎両氏による癌 刺激説の歴史的実験によって獣医学の存在を人々に認識 させたに過ぎない。ことほど獣医・畜産学とは地味な存 在だったのである.ところが近年安全性の問題が的か にクローズアップされるとともに，畜産製品についてる 改めて国民の間で検討されるようになった。当初獣医・ 畜産学関係者の間では「何を,素人が,こんな問題はわれ われ専門家にまかせておけばいいのだ.」といら暗黙の抵 抗と自信があったように感じられる. しかるに飼料に混 入された抗生物質の残留の問題, 疾病の予防治療に用い られた薬剤等の畜産製品への移行の問題, 二セ牛乳, 二 セモノ畜肉製品の問題等々がからみ合うようになってか らは「専門家にまかせて打け」といらょうな観念的な思 想は全く通らないものになった。もらここまでくると 「だまれ，素人」などおこがましき限りである．医学者 の発言, 若手生物学者の介入, 消費者グループの発言等々 いっせいに獣医・畜産学への不信の声, 声である.このこ とは従来の業界・学会には全く見られなかったことなの で, ある学者は沈黙し，ある者は反発し，ある者は同意 と,人それぞれに対応への姿勢はさまざまであった。私は このことの避けられないことをいち早く察知し, 日本獣 医師会内に「有害物質愍談会」を設置して問題の把握と究 明にあたってきたが，何せはじめての試みと問題の異質 性のためか激論激論を重䄪るものの, 結論を未だ会員 に発表する段階に至っていない，㧧のらに問題は重大 であるにかかわらず従来獣医学会, 業界ではそれ程重要 な位置を占めず研究も対応も十分でなかったのである.
ところでわれわれのこの事情とは無関係に，わが分野 以外の発言は急であり,行動もまた極めて活発である.す なわち消費者グループの石油蛋白の飼料化反対の行動は 実に目ざましく国会に, 官庁に, 学会にと縦横無尽の働き を示し，その資料等の検討も若手学者の強力な支援を得 てわれわれよりもむしろ豊富である。また，東大医学部 講師高橋晄正氏（日獣有害物質懇談会委員）は「畜産の 研究」に発表された吉田氏の「抗生物質の畜産食品への 残留」に対して「畜産食品中の抗生物質ゼ口化吉田理論 の批判——危険な科学幻想の根を断て——と「薬のひ ろば」No. 23 で綮しく批判している。 また, テレビ対談 でもしばしば獣医師が登場し, 絶対安全な畜産食品の生 産とこれを国民に提供することが獣医学の真䯣であるこ とを説き世人の注目を集めている。この現実を静かにな がめ私は冒頭に引用した「江戸の水はロンドンに通じて いる」の言葉を強くかみしめるのである，そして今まで の獣医・畜産学はまさに鎖国の状態であり, 黑船の来訪 によって，漸く開国を余儀なくせられたよらな感を深く するのである. そしてわが方には西洋文明なら奴分子生 物学, 分子遺伝学, 毒性学, 統計学, 生化学, 安全性理 論学等の準備があまりにも少ないのに一人おののくので あるが，この際勇気をふるって速やかにないものは吸収 し，他侾光を乞うことが最も大切なことと考光てい る.

私は本稿で 6 年制獣医科大学は物理的に現在の 4 年制 を 2 年延長するのではなく, その質の根本的改革がその 真骨項であると何度も力説した. しかしこのことの正当 性と必要性は獣医学教育の年限延長実施任先立って一足 早く世人は強くわれわれに求めているのであるが，その 対応はどらなのであろらか。私はここに獣医学の現状を 想い, 将来の獣医学を案ずるのである. この際, 同学各 位はこの状況をしかと把握して対処せられんことを強く 望みたい，とくに大学院に進学したもの, 進学しょうと する学徒, そして若手研究者は従来の獣医学の枠を越光 た新たな分野の勉学と研究に向かわれることを願ってや まない，かくすることによって既に本稿で私が述べたよ らな獣医系大学の刷新強化が，はじめて同学の手によっ てなされるものと確信し，かつ期待するものである.

日縜会誌 $28 \quad 437 \sim 456 \quad$ (1975) 
しかし, 現在は数年も待ってくれない. 数年後のこと はそれはそれとして私達は即刻これに対応しなければな らない、それたは重永て強調するがまず, 獣医・畜産学 を鎖国から解くとともに卒直に他に学ぶことである。こ
の资勢をすべての同学がとる時, 獣医・畜産学は世にも 尊いものとして国民に迎党られるであろう。

「汇戸の水はロンドンの水」といら古い言葉を㜱しい 真理として考光てみたい。

\section{全国獣医師会会長会議}

\section{7 月 25 日開催}

7 月 25 日午後 1 时より, 全国獣医師会会長会議が日 本獣医師会館に程近い協栄生命南青山ビル会議室を会場 として開催され, 定款施行細則にも示されていると和り, 中央情勢を報告伝達し，また，地方会の情勢を本会会務 に反映させることとし，最近の諸情勢を勘案して，開催 された。今回は中央情勢の報告以外の協議事項として は，とくに特定の議題を設定せず，地力会長の意見，要 望のきたんのない活潑な意見を閉陳され，祭密なる交流 をはかり，今後の会務に反映せしむることとした。概要 下記のと㧍り。

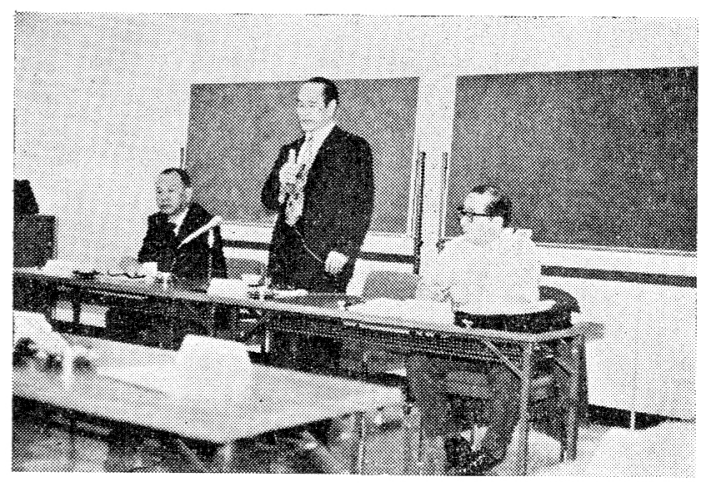

日獣勢行部一中央挨揋の中村会長, 左は樯副会 長, 右は杉山副会長

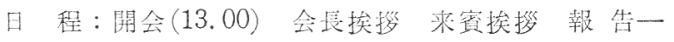
一般業務概沉報告会館建設経過報告臨洔組職財政調 査会経過報告 第 20 回世界獣医会議参加報告一 協議 事項一本会の運営枋つその他一 閉会 (17.00)

中村会長挨拶(要旨)：本日，出席いただいたことを感 謝申しあげる。

日頃ご後援とご協力をたまわり，虰蔭様をもって，本 会運営の進捗をみていることを重ねて厚く叔礼申しあげ る.

地方会と本会との緊密化は極めて重要であり，そのた るにも情報活動の盛んであるべきことの重要性を痛感す ๖.

本会長会議の開催は，定款細則第 9 条，第 10 条に基 つき,これに明記してあると扣り, 地方会長会議を構成
し, また会長会議の決定, 要望等, 地方会の情勢を本会 に反映せしむることにある。

本日の会議にあたり，具体的詳細報告は担当の雨副会 長より報皆されるが，私の真のねらいは地方会の実情を 率直に伝達していただくことにある。

過般の総会, 理事会に蛙いて, 50 年度事業計画 23 項 目を決定し, これが円滑, 迅速に実行, 効果をあげるこ と学審識したが，これに闌一するものである。とくにそ の中で重点4 項をあげ，これらに対する私の意見につい てはその都度会誌等を通じて申し述べてある。

家畜共済, 産業動物対策の問題については, その折衝 状況等についても報告する予定である。また重点事項以 外の項目についても, 重点的事項として重視して沶るも ので, 現今の獣医師の和かれている立場を直視して打開 に努力してゆきたい熱意に然克ている.

教育, 家育共済, 産業動物獣医師問題等々重要なるこ とを認識している.

こらしたことから本日は各位の意見を帱聴し，米月に は理事会開催を予定して抢り，元のためにも本日は有効 的な提案をなされることを拓願いし，勒らかがいいたし たい.

本日の会長会議は從来と趣を異にし，議長を特別に設 げず，私方議事進行者として開催進行いたしたい。本日 はこらしたことから、リラックスしてその実情を反㛟せ しむる心゙く努力してやってゆきたい。

来竇として, 農林省, 厚生省より拓出でいただいたこ と昰括礼时しあげる。

これより本会議を開催いたしたいのでよろしく和頴い 申しあげる。

\section{来寊挨拶：}

農林省䓪産局 白下衛生課長補佐(要旨)：本日全国獣 医師会長会議開催にあたり, 山本衛生課長出席のほずで あったが婜務出張のため, 代わって挨拶を中しあげた い.

最近の竞産情勢として, 需給は, 飼料事情がやや緩和 されてきたが，なお未だきびしい状況下にある。

第75国会に和いては，畜産関係に3法案が諮られた。音 産局関係己して飼料品質改善に関する法律, 家蓄伝染 病予防法改正が審議されたが, 久の審議過程の中で, 今回 泀ど,獣医師問題,家畜衛生問題がクローズアップされた ことは未熋有のことであり, 産畜振興は獣医師問題が先 決であるとして蜜議されたことはうれしいことで, 同時 